\title{
Length-weight relationships of 13 fish species from Pahang River, Temerloh district,
}

Pahang, Malaysia

\begin{abstract}
Length-weight relationships (LWRs) are described for 13 fish species from Pahang River, Temerloh district, Pahang, Malaysia. The river serves as a main water body for freshwater aquaculture in the country and also supplies various fishes for local consumption. This is the first record of LWRs for nine fish species and new maximum lengths for three species in fishbase.
\end{abstract}

Keyword: Length-weight relationships; Fish species; Pahang River; Temerloh district; Pahang; Malaysia 